\title{
When equal becomes the same. The spirituality of sex: Have we lost it?
}

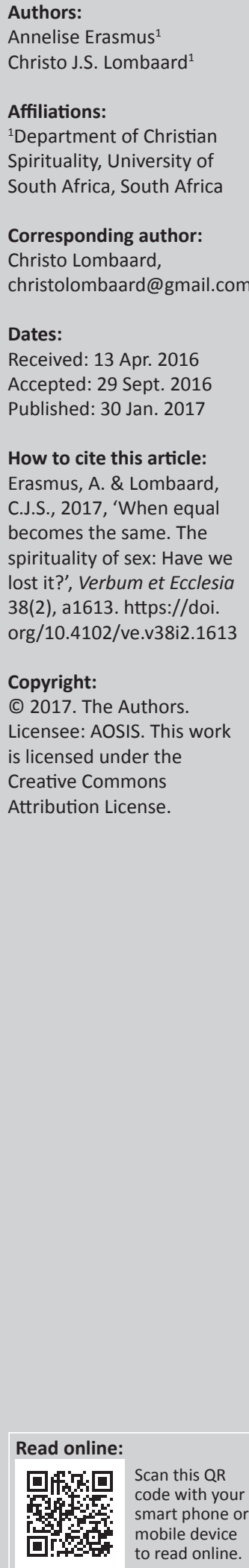

In this contribution, spirituality and sexuality are brought together as part of a quest for authenticity. In conversation with Hegel and Nietzsche, the confusion between sameness and difference as it plays out in the confusion between the public and private spheres is analysed, en route to proposing life-affirming sexual identities, including non-mainstream sexualities.

Intradisciplinary and/or interdisciplinary implications: Aspects of philosophy, spirituality and human sexuality are brought in conversation with one another.

\section{Foreplay}

It is not uncommon for speakers to declare their interests when presenting their research. In my (Erasmus's) case, it would be appropriate to declare, rather, my guilt. As a philosopher as well as a writer of erotic novels (Annelise ${ }^{1}$ 2007, 2008, 2010; cf. Rossouw 2007:s.p., Roux, 2008:s.p. and Diedericks, 2011:s.p.), I have realised that I may well be a part of the problem that I will be elucidating.

I will begin this contribution by explaining what is meant here by sexual spirituality, and by what we have lost. Two possible reasons why what is here termed the spirit of sexuality has been lost will be explored, before finally investigating a possible solution. This will be done by also employing a philosophical narrative about different types of slaves.

\section{The spirit of sex}

There are many definitions of spirituality (Du Toit 2006:49-73 discussed already a decade ago the vast number of uses of this term), with the most extensive exploration of the subject still Kees Waaijman's Dutch magnum opus, Spiritualiteit: vormen, grondslagen, patronen (Waaijman 2000; the internationally more accessible English translation is Waaijman 2002). For the purpose of this article the definition given by Lombaard (2009) will be adopted, because that publication too (titled 'Orgasms and hallelujahs, or, Christian Spirituality and sexuality - a missionary position') is related to the intersection between sexuality and spirituality:

Spirituality may be described broadly as the orientation people have to the 'big questions' of life. Their orientation to issues such as the meaning or purpose of life, whether or not there is life after death, the existence or not of gods, or a god, or God, and whether all these may be experienced, or may be expressed in this life. These are all existential/experiential matters that cannot be studied in any academic way. (p. 107)

To explain the link between such a broadly understood spirituality and sexuality, Lombaard (2009; referring to i.a. Bovell 2007:340-348) continues:

Individualised spirituality could include personal conversion events, mystic encounters, private prayer, and devotional readings, whereas shared spirituality embraces, for example following the liturgy of a religious service, involvement in practical service to the poor, participating in a Bible study group, actions of care for the environment, and other religious acts. These experiences (that is, these lived responses to an awareness of the 'big questions') can be observed and can therefore be studied by scientists from various academic disciplines (such as theologians, psychologists, sociologists). (p. 107)

Spirituality, however, also has a social and cultural aspect. If spirituality is about the big questions of life, it will also be found in the fabric of society. Spirituality informs the values of a society or specific culture. Sheldrake (2013) hence writes:

1.These novels were published under the pen name of 'Annelise', which is the literary pseudonym of the first author of this article.

Note: Paper presented at the 'Post-Secular Stories: The Divine in Contemporary World Literature' conference exploring, LCC Internationa University (www.lcc.It), Klaipeda, Lithuania. The contents of this article reflect part of the work on a Philosophy Master's dissertation titled 'Masters, slaves and spiritual sexuality', written at the time of the conference at the University of South Africa by Annelise Erasmus under the supervision of Christo Lombaard. 
There are signs that the word 'spirituality' is expanding beyond an individualistic quest for self-realization. It increasingly appears in debates about public values, the further development of professional fields, or the transformation of social structures ... (p. 4)

While spirituality is often popularly seen as a subjectively meaningful experience, which it certainly is, it is also a culturally and socially embedded phenomenon, as is commonly pointed out in academic works in Spirituality Studies. This balance between the personal and the transpersonal (the social and cultural dimensions) is equally valid for the experience of human sexuality.

The World Health Association (2006) for this reason too defines sexuality as:
... a central aspect of being human throughout life (which) encompasses sex, gender identities and roles, sexual orientation, eroticism, pleasure, intimacy and reproduction. Sexuality is experienced and expressed in thoughts, fantasies, desires, beliefs, attitudes, values, behaviours, practices, roles and relationships. While sexuality can include all of these dimensions, not all of them are always experienced or expressed. Sexuality is influenced by the interaction of biological, psychological, social, economic, political, cultural, legal, historical, religious and spiritual factors. (s.p.)

Sex and spirituality therefore are no strangers to each other, both phenomenologically and experientially. The link between sexuality and spirituality is therefore acknowledged as having always been there, also from classical antiquity (Bell 1994):

Embodied in the sacred prostitute, in practice and in representation is the unity of womb and clitoris. The temples of sacred prostitution, the best known of which were the temples of Aphrodite in Corinth, were oriented simultaneously to clitoral, uterine, and spiritual purposes: sexuality, fertility, and spirituality were not radically distinguished. (p. 24)

The focus of this article, thus, is sexuality combined with spirituality. Carr (2003) also brings these together through his use of the concept of Eros:

This is a vision of Eros as flavoring all of life. Many people experience such passion most in sexual longing and fulfillment. But others know similarly intense passion when playing music, windsurfing on a sunlit bay, or discussing a new and exciting idea with a friend. So often, the word erotic is taken as equivalent to 'sexual'. Yet the word Eros originates in Greek culture, where it included all sorts of core desires; certainly the sexual, but also intellectual, artistic, and spiritual yearning. (p. 9)

This description fits neatly with Lombaard's 'orientation' cited above concerning the 'big questions'. The fact that Eros is not just about sex but about a way of looking at life is precisely the point of this article. Sexuality has been chosen as the focus of this enquiry, but the arguments applied to sexuality could just as validly be applied to other aspects of life, and vice versa.

\section{What has been lost?}

One may well think of eroticism as the spirit of sexuality. Pretend for a moment that one is writing an erotic story. If you really want to awaken erotic desire on the part of your readers, you have to make them believe that they are part of the story; the reader becomes one of the participants. This can only be done by bringing all the senses into play, along with the reasons why events occur in the way that they do. These 'reasons' can be seen as playing to the mind of the reader, while incorporating smell, taste, sound, the visual and sensations draws in the reader's emotions. Such a capturing of all the reader's senses encompasses something akin to summoning the spirit of sex. In this created literary 'space', sex can transform. It is the opposite of lightness; the erotic reading experience is a surrendering of all the senses to the moment, or more specific yet: a condition conducive to the will to power (to employ here the terminology of Nietzsche, with which he indicates transformative self-actualisation; cf. e.g. Nietzsche 1961).

With spirituality as lived experience, it is my contention here that many have in our time in some sense lost the 'most lived' part of the sexual experience. Sex, today, is therefore for many, and by many, presented as if an author was perhaps too lazy to write in depth, or had forgotten to include all that should be included in such a moment. All that then remains is, in a sense, shallow pornography. What has been lost in such 'unspiritual' sexuality is meaningfulness.

Žižek (2008) notes in this regard about the eponymic writer on Sadism that 'Sade announces the moment when, with the emergence of bourgeois Enlightenment, pleasure itself loses its sacred/transgressive character and is reduced to a rationalized instrumental activity'.

He goes on the say that (Žižek 2008):

... the greatness of Sade is that, on behalf of the full assertion of earthly pleasures, he not only rejects any metaphysical moralism, but also fully acknowledges the price one has to pay for it: the radical intellectualization-instrumentalization-regimentation of the (sexual) activity intended to bring pleasure. Here we encounter the content later baptized by Marcuse 'repressive desublimation': after all the barriers of sublimation, of cultural transformation of sexual activity, are abolished, what we get is not raw, brutal, passionate satisfying animal sex, but, on the contrary, a fully regimented, intellectualized activity comparable to a well-planned sporting match. The Sadean hero is not a brute animal beast, but a pale, cold-blooded intellectual much more alienated from the true pleasure of the flesh than is the prudish, inhibited lover, a man of reason enslaved to the amor intellectualis diaboli - what gives pleasure to him (or her) is not sexuality as such but the activity of outstripping rational civilization by its own means, i.e. by way of thinking (and practicing) to the end the consequences of its logic. So, far from being an entity of full, earthy passion, the Sadean hero is fundamentally apathetic, reducing sexuality to a mechanical planned procedure deprived of the last vestiges of spontaneous pleasure or sentimentality. What Sade heroically takes into account is that pure bodily sensual pleasure and spiritual love are not simply opposed, 
but dialectically intertwines: there is something deeply 'spiritual', spectral, sublime, about a really passionate sensual lust, and vice versa (as the mystical experience teaches us), so that the thorough 'desublimation' of sexuality also thoroughly intellectualizes it, changing an intense pathetic bodily experience into a cold, apathetic mechanic exercise. (n.p.)

Baudrillard (1993) states something in the same vein:

The great drives or impulses, with their positive, elective and attractive powers, are gone. We still desire, but in the feeblest way only; our tastes are less and less highly determined. The constellations of taste and of desire, like that of will, have been blown apart - by what mechanism, we do not know. (p. 72)

In addition, Baudrillard says (1993):

Perhaps we still have a memory of sex, rather as water 'remembers' molecules no matter how diluted. But that is the whole point; this is only a molecular memory, the corpuscular memory of an earlier life, and not a memory of forms or singularities (water, after all, can hardly retain the features of a face, or the colour of someone's eye.) So what we are left with is the simple imprint of a faceless sexuality infinitely watered down in a broth of politics, media and communications ... (p. 9)

Similar sentiments are found elsewhere, even on popular websites such as Spiked (https://www.spiked-online.com; cf. Whelan 2015), where Paglia (2015) said in an interview about current feminism that:
... sex is a physical interaction, animated by primitive energies and instincts that cannot be reduced to verbal formulas. Neither party in any sexual encounter is totally operating in the rational realm, which is why the Greek god Dionysius was the patron of ecstasy, a hallucinatory state of pleasure-pain. 'Yes, means yes' laws are drearily puritanical and literalistic as well as hopelessly totalitarian. Their increasing popularity simply demonstrates how boring and meaningless sex has become - and why Hollywood movies haven't produced a scintilla of sexiness since Sharon Stone uncrossed her legs in Basic Instinct. (n.p.)

In an attempt to put forth a possible explanation for the disappearance of the spirit of sexuality, perhaps a little help may be sought in a story which combines the ideas of some philosophical friends.

\section{A story about the kinds of slaves, I: Hegel, narrated}

In the beginning there was a man alone in his natural state. He desired to be desired by others - to be recognised by them. He could not see himself and needed someone to make him real. His sense of identity and worth was connected to how others saw him. One day this man encountered another man. At first he was elated because he could recognise himself in the other person, and he revelled in their sameness. Man, however, wanted to be recognised as man, and this meant being recognised as someone who was able to risk his life. This led to a violent struggle between the two men - a struggle to be recognised by the other. At the end of this battle a winner and loser emerged. The one decided to submit to a life of slavery rather than die. The victor became his master.
This was the first moment of men relating to each other, as envisaged by Hegel in his famous master-slave dialectic (Fukuyama 1992:147). What happened next in this woeful tale is more interesting and more important for the purpose of this enquiry: the slave turned out to be the one who ended up with a higher realisation of himself. The principle (though a lot more complicated) is akin to what happens amongst children at school: being 'seen' by the captain of the sports team means more than being recognised by the school 'nerd'. The master saw the slave as an object, and thus was not recognised by someone worthy, whereas the slave realised he was subordinate and had the master to feed from.

This narrative is a simplified version of Hegel's concept of the 'struggle for recognition' as interpreted by Kojévé (1969), also referred to in Fukuyama (1992:193). It was intended as a way of describing the important conditions for selfconsciousness or subjectivity.

Sadly, our narrative does not end there. In a very real world roughly a hundred years after Hegel pictured this scenario, a man named Hitler showed what could be done in the name of inequality. He changed the world forever. Which insight may be poetically formulated (here formulated by the first author of this article) as:

$$
\begin{aligned}
& \text { And peace was forced upon the land } \\
& \text { The name of this peace was morality } \\
& \text { and the dove of peace was equality. }
\end{aligned}
$$

These principles fit with Hegel's narrative. He believed that a moral and egalitarian community was required, where subjects could engage mutually in an equal environment and so fulfil the sufficient condition for subjectivity: the full awareness of one's consciousness through the consciousness of another.

\section{The unbearable lightness of sameness}

The general battle for the liberation of the oppressed in many societies over recent decades had two areas of focus important for the purposes of the question raised in this article. The first was the goal of equality for all and the second the tactic of making that which is private, public.

\section{Baudrillard (1993) called this an 'orgy':}

The orgy in question was the moment when modernity exploded upon us, the moment of liberation in every sphere. Political liberation, sexual liberation, liberation of the forces of production, liberation of the forces of destruction, women's liberation, children's liberation, liberation of unconscious drives, liberation of art. (p. 3)

This 'orgy' of liberation had unintended consequences, mostly to do with the dream of equality; it became desirable that all should be equal before the law. However, returning to the insight from Hegel above: Is inequality not a condition for recognition? 
Fukuyama (1992) discusses directly the failures of liberal democracy:

[T]he possibility that liberal society does not represent the simultaneous satisfaction of desire and thymos (self-respect) but instead opens up a grave disjunction between them is raised by critics of liberalism on both the Left and the Right. The attack from the Left would maintain that the promise of universal, reciprocal recognition remains essentially unfulfilled in liberal societies, for the reasons just indicated: economic inequality brought about by capitalism ipso facto implies unequal recognition. The attack from the Right would argue that the problem with liberal society is not the inadequate universality of recognition, but the goal of equal recognition itself. The latter is problematic because human beings are inherently unequal; to treat them as equal is not to affirm but to deny them humanity. (p. 289)

After the Second World War, philosophers had begun rejecting biological approaches to morality, arguing that they ignored basic human sameness and magnified differences that were morally irrelevant. In a world where the current political inclination is towards 'sameness', it becomes increasingly difficult to transcend adequacy. Because history cannot be turned back (and in a political sense there is no desire to return to previous unequal states), the question may be posed whether equality may not have had an adverse effect in certain areas of human endeavour.

One such an area is that of sexual relationships. To be 'different' is to be able to be recognised. As Fukuyama (1992) indicates:

Nietzsche believed ... true freedom or creativity could arise only out of megalothymia, that is, the desire to be recognized as better than others... This desire is not merely the basis of conquest and imperialism, it is also the precondition for the creation of anything else worth having in life, whether great symphonies, paintings, novels, ethical codes, or political systems. (p. 304)

Such desire is also the precondition for spiritual, meaningful sex.

Fukuyama (1992) states in this respect that:

... sexual conquest is usually not just a matter of physical gratification - one does not always need a partner for that - but reflects in addition the need to have one's desirability 'recognised' by the other ... the deepest forms of erotic love involve a longing for the lover's recognition of something more than one's physical characteristics, a longing for what amounts to a recognition of one's worth. (p. 176)

The strong moral obligation to be equal in all spheres of life has, if this line of reasoning holds true, thus impacted negatively on our ability to recognise our partners as different and as worthy.

Baudrillard (1993) puts this differently when he writes on metaphors:

... metaphor is disappearing in every sphere. This is an aspect of a general tendency towards transsexuality which extends well beyond sex, affecting all disciplines as they lose their specificity and partake of a process of confusion and contagion - a viral loss of determinacy which is the prime event among all the new events that assail us. Economics becomes transeconomics, aesthetics becomes transaesthetics, sex becomes transsexuality all converge in a transversal and universal process wherein no discourse may have a metaphorical relationship to another, because for there to be metaphor, differential fields and distinct objects must exist... Perhaps our melancholy stems from this, for metaphor still had its beauty; it was aesthetic, playing as it did upon difference, and upon illusion of difference. (pp. 7-8)

A contemporary example of how far this 'sameness' is being taken is the Free the Nipple Campaign which went viral on social media in December 2014 (https:/ /www.psmag.com/ books-and-culture/expert-weighs-in-on-free-the-nipplecampaign; cf. Wheeling 2015), advocating for gender equality in censorship laws. The organisers of the campaign pointed out that both men and women have nipples, but that only those of women are censored. They maintain that this is because women's bodies are sexualised differently than those of men. Continuing the argumentation above, however, it follows that the campaign against the sexualisation of women's bodies will leave us with nothing but 'meaningless' bodies: there will be no eroticism, no desire, no mystery, no allure, no appeal, no attraction left because women have insisted on becoming exactly the same as men. Nothing is special any longer, because nothing may be recognised as different.

\section{From private to public}

The debate about private and public has too wide a scope to give a fair account of all the important streams of thought in the discourse here. (In this regard, see e.g. Arendt 1958; Chartier 1989; Habermas 1964.) Definitions of private and public have, as would be expected, changed quite dramatically through the ages, morphing yet again with the advent of personal computers and our inter-connectedness through the World Wide Web. In broad strokes, though, humankind started with a state of 'no privacy'. There was for instance no real room for individual solitude in feudal times. There was no privacy or personal autonomy. Ariès (1989) wrote that:

in the late Middle Ages ... many acts of daily life were, and for a long time would continue to be, performed in public... There were places in the community where a precarious intimacy flourished. These were recognized and to some extent protected: a corner by a window or in a hallway, a quiet spot beyond the orchard, a forest clearing or hut. (p. 1)

Today, as the opposite, our lives are compartmentalised into work, home and leisure, and people want privacy - the family has become the focus of private life (Ariès 1989:2). Ariès (1989:1-11) argues that the changing role of the state as well as the spread of literacy, coupled with a new form of religion in the sixteenth and seventeenth centuries, helped to change attitudes about bodies and privacy.

Arendt (1958) discusses another aspect of the 'private' and 'public' based on ancient Greek thought: 
The distinction between a private and a public sphere of life corresponds to the household and the political realms, which have existed as distinct, separate entities at least since the rise of the ancient city-state; but the emergence of the social realm, which is neither private nor public, strictly speaking, is a relatively new phenomenon whose origin coincided with the emergence of the modern age and which found its political form in the nation-state. What concerns us in this context is the extraordinary difficulty with which we, because of this development, understand the decisive division between the public and private realms, between the sphere of the polls and the sphere of the household and family, and finally, between activities related to a common world and those related to the maintenance of life, a division upon which all ancient political thought rested as self-evident and axiomatic. In our understanding, the dividing line is entirely blurred, because we see the body of peoples and political communities in the image of a family whose everyday affairs have to be taken care of by a gigantic, nation-wide administration of housekeeping ... the collective of families economically organized into the facsimile of one super-human family is what we call 'society' and its political form of organization is called 'nation'. (p. 28)

This is precisely the contention here.

Sex and sexuality have in an interesting, unnoticed turn of events been taken from the private and have been made public by the feminist discourse. In a way foreshadowed by the observation by Foucault (1978) that the discourse on sexuality has much to do with power and foregrounding:

[ $t$ ]he concept of sexual politics is at the very heart of modern feminist theory. Like the slogan 'the personal is political' it represents a different way of thinking about male-defined reality, and connects two areas (private $=$ sexual + public $=$ political) which had previously been presumed to be dichotomous. (Tuttle 1986:296)

However, some things are meant to be private. In a subculture, for instance, something is lost when that sub-culture becomes mainstream, and this something usually involves a central identifying trait. When the tension between the private and the public is broken, the taboo which gave the energy that fed the sub-culture, loses its power. The totem has fallen.

To illustrate the point, what is commonly referred to as the BDSM (Bondage, Discipline, Sadism, Masochism) lifestyle may serve as an example here. For the purpose here, the following definition of BDSM may be accepted as a starting point (Edmunds 2013):

BDSM is a culture, community, lifestyle, and identity. The initials refer to many concepts, including Bondage, Discipline, Domination, Submission, Sadism, Masochism, Sadomasochism, and related subcultures of $\mathrm{D} / \mathrm{s}^{2} \mathrm{~B} \& \mathrm{D},{ }^{3}$ and $\mathrm{SM}{ }^{4} \mathrm{BDSM}$ is a distinct culture that holds a set of norms and values that differ from those of mainstream society, with varying levels of

2.Dominant and submissive (with the capitalisation choices reflecting the power relationship).

3.Bondage and Discipline.

4.Sadism and Masochism. participation. It is focused on consensual power differentials and arousal in a theatricalized context, maintained through a wide variety of tools and activities, structured around consent, openness, communication, trust, and safety. (p. 13)

A BDSM scene, referring also in part to Sadism/Masochism, is ultimately a 'game' where - important for the theme of this contribution - power and inequality are used as sexually creative tools. An obvious example from contemporary literature, where a sub-culture which had been essentially private was made public, is the Fifty Shades of Grey series of novels by EL James (with 2011 as the publication date of the first of these) and the subsequent films. Read and viewed by millions, this series tells the story of a couple who dabble in BDSM. The author, however, not understanding the essence of BDSM (as described above), namely the 'recognise' dimension of this lifestyle, exposed a private world to the public gaze, thereby stripping it of its heart, of its spirituality.

In a pseudonymous open letter published on a fetish website (https://www.collarspace.com/viewjournalentry. asp? $\mathrm{i}=1800808 \& \mathrm{bhcp}=1$ ) a participant wrote the following, summarising what has just been indicated - the loss experienced by those in the BDSM community:

I am glad that there are so many new people in BDSM, but it makes me sick to see how so many people are trying to change the lifestyle into something that could possibly fit into 'polite society'. Let me make one thing abundantly clear. We are the outsiders. We are NOT the norm. We are the sexual deviants, the kinky people, the sadistic weirdos, the patched together little humilidolls ... I am a twisted little demon child, and because I found people that are just as twisted as I am, I have found joy and laughter and life. (n.p.)

\section{A story about the kinds of slaves, II: Nietzsche, narrated}

To continue the slave narrative of earlier: One negative result of the moral emphasis on eroding equality is that it has led to humanity becoming level at some of the lowest common denominators. We certainly did not become equal at the level of Hegel's victor (the master); rather, all may have become slaves. Slave morality then becomes the norm and the moral to strive for. Where Hegel's slave had the 'upper hand' in reaching consciousness, we now see a change in the definition of a slave ...

Humanity was thus in need of a new story: one that did not try to eradicate all differences; one that did not give an either / or choice. Nietzsche rendered such a new thought experiment to illustrate this trend. His slave (Nietzsche 2006) has done nothing towards reaching consciousness with the 'benefit' his submissive position gave him; Nietzsche's slave has decided that it would be easier to pull the master down.

Nietzsche did not want only to change society; he wanted to sublimate it. Peace and quiet were decadence in his eyes. So he became an artist instead of a fighter. He believed nothing is good or bad in itself - it all depends on how it relates to 
something (Nietzsche 1966). Nietzsche rebelled against the idea that everything is being levelled. He believed the world is a collection of power struggles, and that we should use it. Good would then be the realisation of potential and evil would be not to realise potential.

He therefore did not believe that people had equal value. Nothing had inherent value - everything had value because it stands in a relationship with something else, but not just one something else (Nietzsche 2001). Although Nietzsche used opposites to illustrate his positions, his philosophy of the will to power was one of degrees of power (Nietzsche 1966).

In On the Genealogy of Morals, Nietzsche (2006) used personified active and passive forces to write a new master and slave story. This one did not lead to recognition, as with Hegel, but to the will to power. These are not types of people (there are namely master and slave impulses in all people). The values personified as the master is active and have a will towards powerful physicality, abundant health, together with hunting, dancing and adventure - all that involves free, joyful activity. These are self-directed and self-affirming activities: the noble impulse is concerned with its selfproduction and expansion, importantly: independent of the other. This impulse looks only to the future. It affirms its own possibilities to becoming, joyously and without fear, and it aspires to height, power and intoxication. This is Dionysian energy.

The slave impulse here is reactive. It is based on resentment, desire for revenge, hate of the other. It is inherently negative and always says no to anything different, to anything not itself. It is bitter: 'His soul squints ...' (Nietzsche 2006:62). It is bound up with the past, never forgets and never overcomes. We have all become slaves. We have lost our Dionysian energy.

\section{Slave encounters of a third kind}

What is put forth here is the contentious idea that Hegel's battle between lord and bondsman is precisely what has been lost in the present world at large, and in sexual relationships particularly. This battle described above alludes to the meeting of two consciousnesses, also in erotic dimensions, and it is when these consciousnesses meet on an unequal ground that growth happens.

In small pockets of resistance against the morality of equality, scenes enacting the meeting of two consciousnesses take place every day. Just as Hegel's tale is fictional and used by him to make a point, and just as Nietzsche's master and slave story points towards personality types, BDSM scenes are also not 'real'. The purpose of a BDSM scene is to play with differences, towards the mutual satisfaction of both the participants.

The work of Foucault, another philosopher who saw life as happening in the tension of inequality, pivoted around asymmetrical relationships. In an interview for the Advocate titled 'Michael Foucault, an interview: sex, power, and the politics of identity', Foucault said (Gallagher 1989):

I think $S \& \mathrm{M}^{5}$ is ... the real creation of new possibilities of pleasure ... they are inventing new possibilities of pleasure with strange parts of their bodies - through the eroticization of the body. I think it's a kind of creation, a creative enterprise ... One can say that S\&M is the eroticization of power, the eroticization of strategic relations. What strikes me with regard to S\&M is how it differs from social power... the mobility in power relations is limited ... the S\&M game is very interesting because it is a strategic relation, but it is always fluid. (p. 26)

It can therefore, following this logic, be said that in BDSM scenes Hegel, Nietzsche and Foucault come together. Dionysius enters the room again. Depths of being are explored. Lived experiences create meaning beyond the conventional. Life is encountered in a primal state.

BDSM, employed here as one example of how sex can be practised spiritually, will always be the domain of a few outsiders, but there may be some basic ideas that can be incorporated into 'broader life'. Nietzsche's solution was to laugh at life - to abandon oneself with Dionysius. 'Socrates said he learned from the priestess Diotima of a nobler form of Eros in which sexual desire can be developed into the pursuit of understanding of the Form of beauty' (Audi 1995:280). Precisely: beauty.

A merger of Hegel's tale and Nietzsche's tale, both as related above, will lead to a positive tension. It is precisely the imaginative play-arena that leads to both the slave and the master being recognised optimally in sexual role play, an element inherent to the BDSM culture. This slave does not have Nietzsche's slave morality. This slave is indeed a master in his or her own right (because he or she enters the game willingly), which means that his or her will to power is driving him or her towards something new. The master knows that the slave is not just an object (as in Hegel's example) and that he or she as master is in effect put into that master position by, therefore, another master - so that the slave (as master, non-master) is also able to reach optimal consciousness. The focus of the relationship is on the area between the two positions - the inequality of power. That is where the erotic soul of sexuality can be found.

Nietzsche believed that even if people were born equal, they would never push themselves to their limits if they simply wanted to be like everyone else. The desire to be recognised as superior to others is necessary if one is to be superior to oneself. He pointed out that any form of real excellence must initially arise out of discontent, a division of the self against itself and ultimately a war against the self with all the suffering it entails; 'one must still have chaos in oneself to give birth to a dancing star' (Fukuyama 1992:304).

The possibility for sex to give rise to such a dancing star has been lost when the conditions necessary for it have been lost. Fukuyama (1992) leaves us with but a glimmer of hope:

5.A more common abbreviation for Sadism and Masochism 
No regime - no 'socio-economic system' - is able to satisfy all men in all places. This includes liberal democracy. This is not a matter of the incompleteness of the democratic revolution, that is, because the blessings of liberty and equality have not been extended to all people. Rather, the dissatisfaction arises precisely where democracy has triumphed most completely: it is dissatisfaction with liberty and equality. Thus those who remain dissatisfied will always have the potential to restart history. (p. 334)

\section{Conclusion}

To be sure: nobody wants to return to a society where people do not have equal rights and equal opportunities; such a return is certainly not what is advocated here. Some ideas, however, are meant to be revisited because in some cases the 'safe' way may not be the best way. It is the dangerous ideas that lead to something new, something exciting and invigorating. In cahoots with Nietzsche, and reinterpreting Hegel, it may be possible to find a spiritual dimension - a small pocket of our existence - where we can still be larger than life within our sexual selves.

\section{Acknowledgements Competing interests}

The authors declare that they have no financial or personal relationships which may have inappropriately influenced them in writing this article.

\section{Authors' contributions}

A.E. is the main author of this work, including also the central insights. C.J.S.L. acted as supervisor, adding some sections, streamlining the argumentation and taking care of the editorial processes. The content of this article reflects part of the work on a Philosophy Master's dissertation at the University of South Africa titled 'Masters, slaves and spiritual sexuality', written at the time of the conference at which this article was presented as paper by A.E. under the supervision of C.J.S.L.

\section{References}

Annelise, 2007, Maanvrug, Goddess Unlimited Communications, Pretoria.

Annelise, 2008, Weerloos, Goddess Unlimited Communications, Pretoria.

Annelise, 2010, Slavin, Goddess Unlimited Communications, Pretoria.

Arendt, H., 1958, The human condition, The University of Chicago Press, Chicago, IL.

Ariès, P., 1989, 'Introduction', in R. Chartier (ed.), A history of private life, III: Passions of the renaissance, pp. 1-11, The Belknap Press of Harvard University Press, Cambridge, MA.

Audi, R., 1995, The Cambridge dictionary of philosophy, Cambridge University Press, New York.
Baudrillard, J., 1993, The transparency of evil. Essays on extreme phenomena, Verso, London.

Bell, S., 1994, Reading, writing, and rewriting the prostitute body, Indiana University Press, Bloomington, IN.

Bovell, C.R., 2007, 'If scientists can naturalize God, should philosophers re-naturlize Him?', Theology Today 64, 340-348. https://dx.doi.org/10.1177/00405736070 6400305

Carr, D.M., 2003, The erotic word. Sexuality, spirituality, and the Bible, Oxford University Press, Oxford.

Chartier, R., (ed.), 1989, A history of private life, III: Passions of the renaissance, The Belknap Press of Harvard University Press, Cambridge, MA.

Diedericks, E., 2011, Vir kop én lyf, viewed 26 January 2016, from https://152.111.1.87/ argief/berigte/rapport/2011/04/05/RH/11/boek11-erotika.html

Du Toit, C., 2006, 'Secular spirituality versus secular dualism: Towards postsecular holism as model for a natural theology', in C.W. Du Toit \& C.P. Mayson (eds.), Secular spirituality as a contextual critique of religion, pp. 49-73, Research Institute for Theology and Religion, University of South Africa, Pretoria.

Edmunds, A., 2013, BDSM: What is that? Seeking a definition to the mis/undefined (MA Integrated Studies Final Project), Athabasca University, Athabasca, Alberta, viewed 24 November 2014, from https://dtpr.lib.athabascau.ca/ action/download.php?filename=mais/700/autumnedmonds-project.pdf

Foucault, M., 1978, A history of sexuality, Penguin Books, London.

Fukuyama, F., 1992, The end of history and the last man, Penguin Books, London.

Gallagher, B., 1989, 'An interview: Sex, power and the politics of identity', Advocate 8/7/84 (400), 26.

Habermas, J., 1964, The public sphere: An encyclopedia article, viewed 04 December 2016, from https://unige.ch/sciences-societe/socio/files/2914/0533/6073/ Habermas_1974.pdf

James, E.L., 2011, Fifty shades of grey, Vintage Press, New York.

Kojévé, A., 1969, Introduction to the reading of Hegel, transl. J.H. Nichols, Basic Books, New York.

Lombaard, C., 2009, 'Orgasms and hallelujahs, or, Christian spirituality and sexuality: A missionary position', Missionalia 37(1), 103-123.

Nietzsche, F., 1961, Thus spoke Zarathustra, transl. R.J. Hollingdale, Penguin Books, London.

Nietzsche, F., 1966, Beyond good and evil, transl. W. Kaufmann, Random House, New York.

Nietzsche, F., 2001, The gay science, transl. J. Nauckhoff, Cambridge University Press, New York.

Nietzsche, F., 2006, On the genealogy of morality, transl. C. Diethe, Cambridge University Press, New York.

Paglia, C., 2015, 'Feminist trouble', Spiked Review, viewed 26 January 2016, from http://www.spiked-online.com/spiked-review/article/feminist-trouble/17688\#.VGNC5N95sM

Rossouw, J., 2007, Méér as net 'n soete, erotiese vrug, viewed 26 January 2016, from https://m24arg02.naspers.com/argief/berigte/dieburger/2007/05/05/BJ/5/ asrossouw-551.html

Roux, J., 2008, 'Weerloos' is wys, intelligent, uniek en knap geskryf, viewed 26 January 2016, from https://152.111.1.87/argief/berigte/dieburger/2008/12/02/SK/15/ BBjrouxWeerloos.html

Sheldrake, P., 2013, Spirituality. A brief history, 2nd edn., Wiley-Blackwell, Oxford.

Tuttle, L., 1986, Encyclopedia of feminism, Arrow Books, London.

Waaijman, K., 2000, Spiritualiteit: Vormen, grondslagen, patronen, Carmelitana, Gent. Waaijman, K., 2002, Spirituality. Forms, foundations, methods, Peeters, Dudley, MA.

Wheeling, K., 2015, Will the free the nipple campaign lead to gender equality? An expert weighs in, viewed 15 January 2016, from http://www.psmag.com/booksand-culture/expert-weighs-in-on-free-the-nipple-campaign

Whelan, E., 2015, Feminist trouble, viewed 15 December 2015, from http://www. spiked-online.com/newsite/article/feminist-trouble/17688\#.VqeJI_I96M8

World Health Organization, 2006, Sexual and reproductive health, viewed 10 November 2014, from http://www.who.int/reproductivehealth/topics/sexual health/sh_definitions/en

Žižek, S., 2008, Radical evil as a Freudian category, viewed 10 January 2016, from https://www.lacan.com/zizlovevigilantes.html 